\title{
Integration Research of Family Education and Moral Education for Youngsters
}

\author{
Jian-Hong LU \\ Institute of Life Sciences and Food Engineering, Shaanxi Xueqian Normal University, Shaanxi, \\ China;
}

azurelu2008@163.com

Keywords: Family Education to Youngsters', Moral Education, Problem Research

\begin{abstract}
This paper is mainly to investigating and analyzing the current situation and problems of Chinese family education, moral education and putting forward some effective countermeasures about the social phenomena of stressing intelligence and ignoring morality, emphasizing breeding while overlooking educating, focusing on the language training while neglecting the behavior models in current family education. It impels people to reconsider the real value of family education, and reassess the different position of morality education and intellectual education so as to explore the fine traditions of family moral education, renovate he moral transmission chain and fully enhance the moral education efficacy of teenagers.

With the development of the economic globalization, there is an urgent need for the integrated people with high cultural qualities and moral accomplishments, and the youngsters which are the successors and the main force of the future social development, their moral education is received extensive attention from our government and society. Families are the basic units of the society and the main positions of the youth activities. Therefore, to grasp the moral education function of family education and promote the moralities of youngsters are the keys for the scientific researchers to teaching and studying.
\end{abstract}

\section{Introduction: the Concepts of Family Education and Moral Education}

Dictionary of Social Science defines family education as the parents or other elders educate and affect the youngsters consciously and proactively within their own family environment. The researchers of modern educational theories tend to emphasize the interactive relationship between parents and children in education in the definition of family education. This study mainly chooses 12-18 year-old youngsters which are in the stage of fast-growing in physiological maturity and mental growth. These youngsters also begin to make the self-judgment consciously with certain independent consciousness, and their world views and moral ideas are vulnerable to the external factors. Therefore, the family education is defined to parents or other elders to affect the youngsters purposefully and consciously in the domestic sphere through the family education concepts, family education methods, family education content and family education environment.

Moral education is the product of social culture with rapid development. In ancient China there is no complete concept of "moral education", many educators only use "DAO" or "DE" to express, in the contemporary time they use "XUNYU" and "PINXING EDUCATION". With the introduction of western educational thoughts, the concept of "moral education" was gradually used. Nowadays, scholars in China have gradually reached a consensus on the understanding of moral education. Such as the "Education Dictionary" edited by1987 defines moral education to the ideological and moral work to train the youngsters in school. "Moral Education Dictionary" edited by 1989 defines the concept of moral education as to that educators exert various planned and purposeful influences on the educated to adapt the social developing requirements. In a word, moral education that means educators affects the youngsters in education of ideological and political and moral aspects by different ways, according to the characteristics and laws of the formation of different ages to satisfy the requirements of the educated and the society. 


\section{The Problems of Family Education from the View of Youngsters Moral Education:}

Various bad habits and customs of parents make family education lie in many problems in educational concept, educational content, educational method and educational background.

\section{Family Education Concept is rigid and Family Education Content is Narrow-Minded.}

As affected by the traditional thought for thousands years, the status of parents and children in our family education is extremely unequal. Parents always ignore their children's subjectivity in family education, regard them as family attachments, and be led and controlled by their parents. The Convention on the rights of the child proposes that children, like adults, should equally enjoy equal values and advocate equal relations between parents and children. Most parents neglect their children's personality, and imposed their expectations on children, always cultivate youngsters as their subjective willingness. Thus makes youngsters form the rebellious psychology and exert a negative impact on youngster' outlook on life. Meanwhile, most of parents consider families as the second place of school education. They always emphasize the importance and urgency of learning knowledge, makes family education liable to impart school knowledge, which replaces the moral education and causing the imbalance of youth development.

With the improvement of people's living standard, the educational investment for youngsters is increasing nowadays, but as the one-sided family education, there is an imbalance between teaching and raising, wisdom and virtue, language training and behavior models in family education. 1) Stressing intelligence and ignoring moralities. Most parents think that moral values are too abstract, and their children are still too young to foster the moralities. Other parents think that moral education is the task of schools and society, and they only need to pay more attention to their health.2) Emphasizing breeding and overlooking educating. Parents generally consider scores, achievements as the standard of children's progress, make the intelligence training as the only way for the success. They hope their children to receive higher education, engaged in a good salary job, eventually ignore the ideological and moral cultivation. 3) Focusing on the language training while neglecting the behavior models. Youngsters' cognitive abilities and understanding abilities are poor, parents often use old sayings to instill moral contents to children, which lacks of actual life behavior model. Thus moral education system formed by abstract preaching is easily disintegrated by the impact of outside information.

\section{Family Education Methods are Simplified and Family Education Background is Usually Complicated.}

"Grandfather inherits to his FATHER, father inherits to ME, I inherit to my SON." This is the inheriting way of family education in our country. The education method is lacking of theoretical guidance which is always liable to personal and subjective. There are many problems in the educating process. 1) Spoiling too much to limit the potential development of teenagers. The excessive doting on youngsters leads to many defects in their personalities and hinders their potential development. 2) Overindulgence has weakened the moral function of family education. Parents neglect youngsters' education because of their busy work. In order to make up for the mistakes, they continuously meet the various requirements of youngsters with no principles. 3) Educating despotically inhibits the development of youngsters' personalities. "Stressing intelligence and ignoring morality", "valuing power and neglecting responsibility" are typical manifestations of it. 4) Simplifying educating methods stimulate the reverse psychology of youngsters. They are impulsive, sensitive, emotional, alert, and unwilling to be controlled by their parents, and they are prone to rebel against their parents. The simple and brutal way of teaching not only hurts their body, but also hurts their minds.

At present, there are three points about the complication of family education background in our country. First is the blind investment in family education. With the development of economy, the investment in family education is increasing year by year. People always pay more attention on school education, and skills training, lacking of rational investment and emotional investment, mainly focus on the material, with the wrong thought that the more attention and money we spend on education, the 
better effect of it we get. Second is that the lack of fair education. Because of the difference of the family education environment in primary stage of youngsters, such as parents' income and their different social status, all of these reasons make youngsters receive unfair education and even make small part of them form the inferiority cowardly character. Third is copying the foreign experience. In absorbing the western family education, there is a misunderstanding which is that people always exert foreign experience mechanically and often be puzzled in the conflicts of the two thoughts. With the introduction of educational thought on different values and ethics, youngsters will suffer more extensive influence.

\section{The Integration Analysis on the Problems of Family Education in view of the Moral Education.}

After the questionnaire survey of our university, Shaanxi Xueqian Normal University, and consulting a large number of literatures, author mainly analysis the factors of affecting the family moral education function from the three dimensions of family education, school education and social education.

\section{Family Educational Values are Utilitarian}

At present, there is a serious utilitarian mentality in Chinese educational circle, and educators ignore to cultivate youngsters' sense of morality and responsibility. Parents always stress knowledge educating and ignore the ability fostering, emphasize the final results and overlook the striving process for the influence of money, vanity, and the negative social phenomenon. They blindly hope the success of their daughter-and-son's to satisfy their material and spiritual needs and form the educational expectation of "high scores, high officials, well education and salary". In this circumstance, youngsters will make two kinds of reactions: (1) Youngsters make "money and power" as their goal for following their parents' moral values. (2) Conflicting with the viewpoints of parents, but eventually yield in the pressure. Utilitarian family education is a typical product of "examination oriented education", it is a short-sighted educational behavior and great crisis of modern education".

\section{Parents' Bad Language Communicating and Behavioral Modeling Often Cause the Positive Influence.}

The saying of "parents are the first teachers of their children" emphasizes the guiding role of parents in family education. Good words and deeds of parents can greatly promote the development of children's moral education, and they will have a far-reaching influence on youngsters' growth. Similarly, bad words and deeds will not only reduce the adverse effect of the family moral education of youngsters, but also weakens the effect of moral education in schools and society, hinder the overall development of youngsters. Usually, most parents can consciously pay attention to their behaviors in front of their children, but it is undeniable that there are still some parents due to their own reasons or environmental impact, make the wrong words and deeds model for children, such as vulgar language, not filial piety, neighborhood discord, often quarrel, corruption, negative attitude, feudal superstition and so on. All of these deeds or words make the parents' wrong ideological and moral values and behavior model as the model of youngsters' and formation of bad moral character and life attitude.

\section{The Influence of Family Structure Changing}

For the influences of national economic system transformation, the national policy of family planning, people's concept of marriage and other factors, the structure of family members has become more diversified which formation the rural left-behind children, migrant children and unemployed youth, plight youngsters, single parent families, adoptive families, remarried families and other groups. This study does not elaborate on all the family structures, only chooses the representative groups of migrant children, rural left behind children, single families, and the remarried families to analysis. Broken family relationship brings great obstacles and negative influence to carry out family education, and let the youngsters lose the trust of their parents, and reduce the intimate relation, even some 
youngsters are in the circumstance of both parents do not fulfill the educating obligations. Many adults choose to restructure their families after the divorce, but in the process of restructuring they take little notice of their children's emotions and feelings, always neglect the integration and communication of family members after family reorganization. In the family relationship is not harmonious atmosphere, parents of moral education for their children is almost blank, youngsters are liable to form a closed, low self-esteem, world weary psychology. Whether parents' relationship is harmonious or not is an important factor for youngsters' health.

\section{Family Education Lacks Feasible System Guarantee}

China has promulgated the "Teacher Law", "Compulsory Education Law", "Vocational Education Law" and other laws or regulations to protect the majority of youngsters' right to education, but rarely issued specific regulations on family education. In 1992 the implementation of "The Law of the Protection of Juveniles" specially formulated the items of "family protection law ". It mainly to protect the upbringing of youngsters, guardianship and their legal rights, but its operability is not strong, the individual terms did not make penalties, responsibility is not clear. And it proposed that "to formulate and improve relevant special laws to protect the rights of children such as prenatal health care law, family education law....." in the "China Development in China in the1990s" which was issued in the same year. Educational Behavior Standard of Parents was formulated in 1997, but for its too theoretical terms made the operability reduce much. Law is an effective means of moral transmission, and morality is a useful supplement to the law. But to now, family education, as an important component of education system, has no special legislation in the aspects of organizational form, management mechanism and system guarantee ${ }^{[4]}$.

\section{The Effective Measures to Improve the Moral Education Function of Family Education in China}

Herbart, a German educationist, once pointed out that the whole and only purpose of education is moral education. In the new period of social development, the cultivation of young people's good moral character has become the primary task of social development.

\section{Renewing Educational Concepts and Improving Family Education Methods}

Parents should correct their own understanding and reconsider the position of moral education and intellectual education. Parents should stress both morality and intelligence, and enhance the moral education in intellectual education, to foster the intellectual education in moral education, which to develop and promote the two kinds of education. Kohlberg, a famous educationist, points out that moral development of human beings is similar to cognitive development in his theory of moral development. Piaget's stimulus response formula: $S=(A T)$ - R. ("S" stimulus, "R" for the reaction, "T" for cognitive structure or cognitive schema, "A" for assimilation, "AT" was assimilated by cognitive stimulation). He pointed out that people's moral quality is to choose, filter, assimilate and integrate by the existing moral cognitive schema to gradually develop the moral behavior according to the moral cognition the moral choice.$^{[5]}$ In other words, the cultivation of moral character, like intelligence training, it requires a process of learning and internalization. However, the improvement of intelligence does not necessarily lead to improvement of moral education. Therefore, we should emphasize both the intellectual education and the moral education in the educating process of youngsters'.

\section{Improving the Quality of Family Educators}

Parents are the first teachers for youngsters who affect most and last longest to them. The moral accomplishment of parents directly influences the development of youngsters' moral qualities. On the one hand, parents should cultivate noble moral and psychological qualities. Moral quality is the foundation of being a man, and it is also the primary quality of being a parent. Parents' good quality demonstration is the best way to cultivate youngsters' character. At the same time, parents' 
psychological state plays an important role in their moral education. Therefore, parents should also pay attention to learning, popularizing psychological knowledge and mastering certain psychological adjustment skills. On the other hand, parents should improve their cultural quality and moral educating ability. A certain cultural accomplishment of parents can satisfy youngsters' eager for knowledge and master the initiative of moral education. And moral education ability is also an important factor in the quality of parents. Parents should consciously communicate with other parents and educational experts, and improve their moral quality and moral education ability constantly.

\section{Enrich the Content of Family Education}

The author mainly puts forward several overall education contents which are just suitable for children's virtue development in the view of juvenile moral education. The first is to advocate etiquette education. China is a state of ceremonies. However, nowadays parents ignore the etiquette education for youngsters. Actually, to enhance the cultivation of the spirit of etiquette is essential from the adolescent years. Youth etiquette education should start with personal etiquette and communicative etiquette. The second is to pay attention to character education. Character is an indispensable moral character for young people to grow up. It mainly includes integrity, courage, kindness, diligence, responsibility, obligation and independence. Parents should create some practical activities which are conducive to the initiative and creativity of young people, and make them to experience and develop good qualities in their participations. The third is to use love education. The love of parents and teachers should be a genuine, equal, and nun-stopping love. When parents carry out "love education", they should show the reasonable love, the moderate love, using sincerity to foster sincerity. The fourth is to strengthen the legal education. Family legal education is of great significance to the health of youngsters. If we want to change the current situation of parents which neglects of legal education, the primary task is to enhance the legal awareness of parents' education, and to establish the concept of family education firmly in accordance with the law of education. We should cultivate the youngsters to the new era successors who can learn, abide of and cherish laws consciously with the high sense of social responsibility.

\section{Optimizing the Family Education Environment}

The democratic, harmonious and clean family education environment is not only conducive to learning knowledge, improving abilities, but also help to foster the positive life mentality for youngsters to promote their healthy growth. We should create a democratic atmosphere and optimize the family environment. In a harmonious family relationship, children will deepen their trust in their parents, form a positive, optimistic and confident attitude towards life, and they can feel the warmth and belonging of the family. Meanwhile, the harmonious family relationship helps parents achieve a coherent education philosophy and methods. We should change the learning thought and optimize the cultural environment. Parents should provide a clean and neat living space for their children. Parents should pay attention to broaden their knowledge, learn synchronized with youngsters, and construct the learning family mode for applying to the lifelong learning of modern education. They also should expand the youth knowledge, exert the patriotism education and cultivate the personal aesthetic by leading youngsters to the libraries, museums, art galleries and other places.

\section{Enhance Communication and Cooperation between Family, School and Society}

Chinese government pays high attention to the education problems for the cooperation for families and schools, which has issued various policies and resolutions, and stressed that "family education plays an important role in the ideological and moral education of youngsters. We should unite family education, school education and social education together." We can run the parents schools or Parents Association to reach an agreement between school education and family education. On the one hand, we should strengthen communication and cooperation between families and schools, and affirm the basic role of schools in the moral development of youngsters, even to guide the direction of moral education for family education. On the other hand, we should strengthen the communication and 
cooperation between families and societies. Government should intensify propaganda, embody the importance of moral education, set up moral model characters, and exert the positive role of moral example. Meanwhile, we should formulate relevant policies and regulations to promote education equity. Supervisions of public security, national culture, publishing and other law enforcement departments should strengthen, and end the influences of toxic violence, pornography and obscenity, superstition for youngsters, so as to create a good cultural environment for the national ideological and moral construction and the healthy growth of youngster.

\section{Conclusion}

In conclusion, family education, school education and social education constitute the modern education system, the development of youngsters' moral education as the main content of modern education, which is inseparable the coordination of families, schools and societies. Therefore, we should cooperate to build a new system of moral education in the Trinity, family, school and society, which adheres the family education to the basis, and school education as the guidance, and social education as supplement.

\section{Acknowledgement}

This research was financially supported by the Educational Science Research Project of Shaanxi Province(SGH170703)and the Science Research Project of Shaanxi Xueqian Normal University (2017YBRS051).

\section{References}

[1] FB Edge. Book Review: IV. Practical Studies: Moral Education in Family, School, and Church [J]. Review \& Expositor , 2003(3).

[2] E. Bameri Analysis and Prioritization of Moral Education Injuries in the Family: Case Study of Khash City [J].Mediterranean Journal of Social Sciences MCSER Publishing, 2016(7).

[3] V. Iosifescu. Conformity and Contradiction Concerning Moral Education in Family and in School [J]. Lucră ri Ș tiinț ifice 2009(52)

[4] A.I. Anakwe. The role of the family in moral development of primary school children in Jos-South of Plateau State [J]. Journal of Childhood and Primary Education .2008(5) 25-30

[5] C.O. Musa, Some causes of moral laxity among youths in Jos-North [J]. University of Jos.2004

[6] Benjamin Jowett. The Four practice Dialoguer of Plate [M]. London: Oxford press, 1995.

[7] Kellaghant. Family and Schooling in Lawrence [J]. International Clopedia of the Sociology of Education. Oxford UK: 2007(5) 